\title{
ALEXANDRIA'S CULTURAL LANDSCAPES: HISTORICAL PARKS BETWEEN ORIGINALITY AND DETERIORATION
}

\author{
NOURHAN H. ABDEL-RAHMAN \\ Faculty of Engineering, Department of Architecture, Cairo University, Egypt
}

\begin{abstract}
Alexandria is one of the largest cities in Egypt in terms of population and urban density, second only to Cairo. Since its origination in the 300s BC, it has been one of the biggest metropolises in the ancient world, culturally, intellectually, politically and economically. Alexandria's classy urban environment over the different eras was always reflected in the creation of gardens and public spaces for its residents since the Ptolemaic era. This paper aims to present a descriptive profile of the historical parks and gardens in Alexandria, and to track the evolution of these parks, from their initial design to their current state today. This record introduces a comparative criticism of the historical and physical deterioration of these valuable landscapes. The paper also reviews the urban growth of the city and encroachment over these parks through time. The parks and gardens under review are Nozha Complex, which includes Antoniadis Garden, Nozha Garden, Rose Garden, and Alexandria Zoo Garden; as well Montazah Gardens and Shalalat Gardens. These parks are examined individually in terms of their history, significance and evolution.

Keywords: Alexandria, historical parks, urban deterioration, cultural landscapes, Antoniadis Complex, Montazah Gardens, Shalalat Gardens.
\end{abstract}

\section{INTRODUCTION}

One of the most resilient ways of preserving the collective memory of history is through historical open spaces, i.e. landscape settings. Messages and memories reserved in historical public spaces are worth more what written words can deliver. As a historically intense city, Alexandria's context carries endless chronicles within its open spaces. The evolution and changes that affected these spaces throughout time are worthy of documentation, analysis and knowledge-based interventions. Today, public parks and gardens in Egypt are generally deserted, ignored, rapidly deteriorating - even vanishing sometimes - in terms of components, historical design and physical area. Since Alexandria is a historical city that goes back to the Ptolemaic era, nearly all its parks are historical landscapes, which emphasizes the grave need to keep these parks intact and in proper condition.

In order to understand the dilemmas and urban derivatives that lead to the current deterioration of historical parks in Alexandria, this paper proposes an analytical overview of the principal historical parks and gardens in the city, in an attempt to understand their evolution through time, since their initiation and design, till their current condition. The study aims at untangling the interrelations between the different variables and factors that might have affected each of the studied parks and altered its original status.

\section{ALEXANDRIA CITY: CONTEXT OVERVIEW}

Being the second biggest city in Egypt, second to only Cairo [1], Alexandria has proven to be as important as the Egyptian capital itself over time. According to the UN report for State of the World's Cities in 2013, the city population growth rate of urban agglomerations for Alexandria have always been higher than that for Cairo since 1990 all the way through to the expected growth rate in 2025 for both cities [2]. It's also worth mentioning that it actually was the Egyptian capital in starting from the Ptolemaic Era [3] in $331 \mathrm{BC}$ till Arabs conquered 
Egypt in 641 AD. After its origination in the 300s BC, it has become in no time the biggest metropolis in the ancient world, culturally, intellectually, politically and economically [4].

Regarding cultural backgrounds, Alexandria is considered the most multi-cultural and extremely diverse city in Egypt. This related to the Mediterranean as well as global integration and exposure that made Alexandria an approachable and liveable city for different nationalities and ethnicities. This also reflects on the names of the Alexandrian district; Greek names such as "Bacus" (Bacchus), Ptolemaic names such as "Soter", Roman/Coptic names such as "San Stefano", Arab names like "Shatby", Jewish names such as "Semouha", modern European names like "Stanley", and modern Egyptian names like "Moustafa Kamel" [5].

\subsection{Historical parks in Alexandria}

Since its foundation in the roman period, Alexandria always exhibited a classy urban environment throughout the variously rich eras that have come over the city. The high quality of the urban environment in Alexandria was emphasized by creating gardens and public spaces for the community since the Ptolemaic era $(300 \mathrm{BC})$. "There were many parks and gardens; for the Alexandrians shared the Egyptian love for flowers, and the flower-sellers and sellers of garlands were a familiar sight in the streets" [4]. An example of the ancient gardens in Alexandria since the Ptolemaic era is the Nouzha Complex (investigated below). This complex forms part of a group of gardens located east of Alexandria city along the Mahmoudiyah Canal, and still standing till our present day, making it one of the most ancient gardens in Egypt and the Middle East [6], [7].

\subsection{Indicators for choice of studied parks}

It is worth mentioning that the choice of historical parks to be reviewed in this paper was based on unified criteria of choice, which would offer a comparable framework that would help formulate a holistic interpretation of the historical park scenery and evolution in the city. These criteria are:

1. The park/garden is a geographically situated within the historical urban fabric of the city.

2. The park/garden exhibits historical values and significance in terms of its foundation date, relation to historical events, as well as reflections on the lives of historical figures. Contemporary parks are excluded from the scope of study.

3. The park/garden should be current existing within the city, even if its area has decreased or has been partially lost to urban growth.

4. The park/garden is used for public enjoyment and open to the community. Gardens and parks that are currently restricted from public use or have been transformed into a private ownership are not included in the study.

\subsection{Studied historical parks}

The parks and gardens included in this research have been gathered from different resources and assessed according to the abovementioned criteria. Accordingly, the parks and gardens under review are Nozha Complex, which includes Antoniadis Garden, Nozha Garden, Rose Garden, and Alexandria Zoo Garden; as well Montazah Gardens and Shalalat Gardens (as shown in Fig. 1). These parks are examined individually in terms of their history, significance and evolution. 


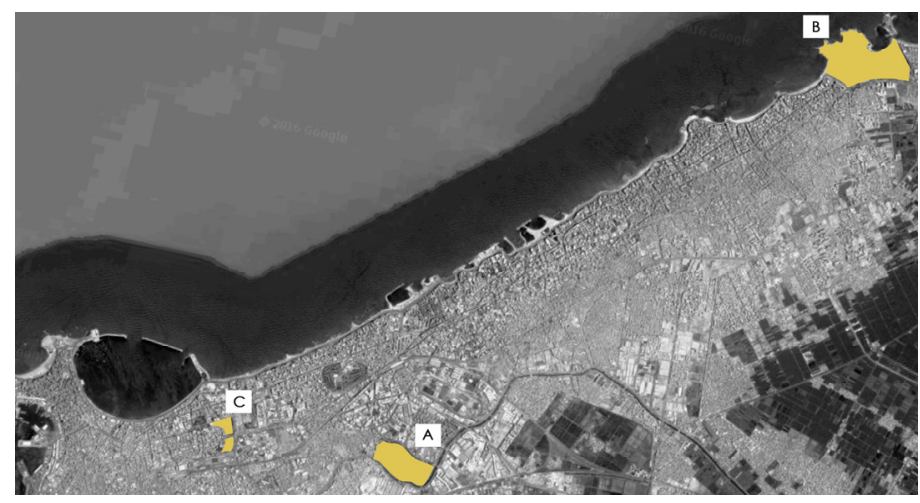

Figure 1: Map of Alexandria showing studied parks and gardens. A: Nouzha Complex; B: Montazah Gardens; C: Shalalat Gardens. (Source: Google Maps, 2016; Author.)

\section{ANALYTICAL FRAMEWORK}

In order to capture key changes and major evolution dilemmas in the studied historical parks and gardens, different variables and crucial aspects have been taken into consideration. These include primarily the historic significance of the place, and how its oral history as well as its physical design incorporate to its significance, as well as how these historic values have been passed or altered throughout the different generations. Another important aspect is also the identity of the park or garden as a place inside the city, as well as an interactive space, which highlights the importance of the activities and their evolution through time. The physical deterioration of the function, activities and substantial design of the park is also crucial to analyse, whether this deterioration has taken place in terms of physical wear, or through the loss of parts of the park to the city's growing urban environment. This adds to management of the park in terms of municipal involvement and concentration of funds or lack thereof.

\section{PARK/GARDEN ANALYSIS}

\subsection{Nouzha Complex}

Nouzha Gardens Complex is the most ancient garden in Alexandria, dating back to the Ptolemaic period (300 BC). It forms a group of gardens located east of Alexandria city along the Mahmoudiyah Canal. Although the place was considered a public area throughout the different historic eras, the official gardens were constructed in 1820 during the reign of Mohammed Ali Pacha. They were known as 'Pastré gardens' as they once belonged to a Frenchman known as Pastré who was gifted them by Mohammed Ali. However, they were later bought back by Khedive Ismail together with the surrounding land, which he then planted with rare plants and trees to look like the Bois de Boulogne in Paris [6], [7]. The development of the complex through time is illustrated in Fig. 2 below. The current divisions of the complex are shown in Fig. 3.

The complex has two entrances: one on the northern side, the Somuha entrance, and the other from the south, the Mahmoudiyah entrance. The latter is characterized by an iron gate ornamented with a royal crown and white marble lions installed above each pier, a gift from General Mohammed Mahmoud Mokhtar to Alexandria in 1929, taken from his own palace [6]. The Nouzha Complex Gardens include many palm and palm-like plants (cycads) along with a large group of trees, shrubs, climbers, perennial and annual flowers. 

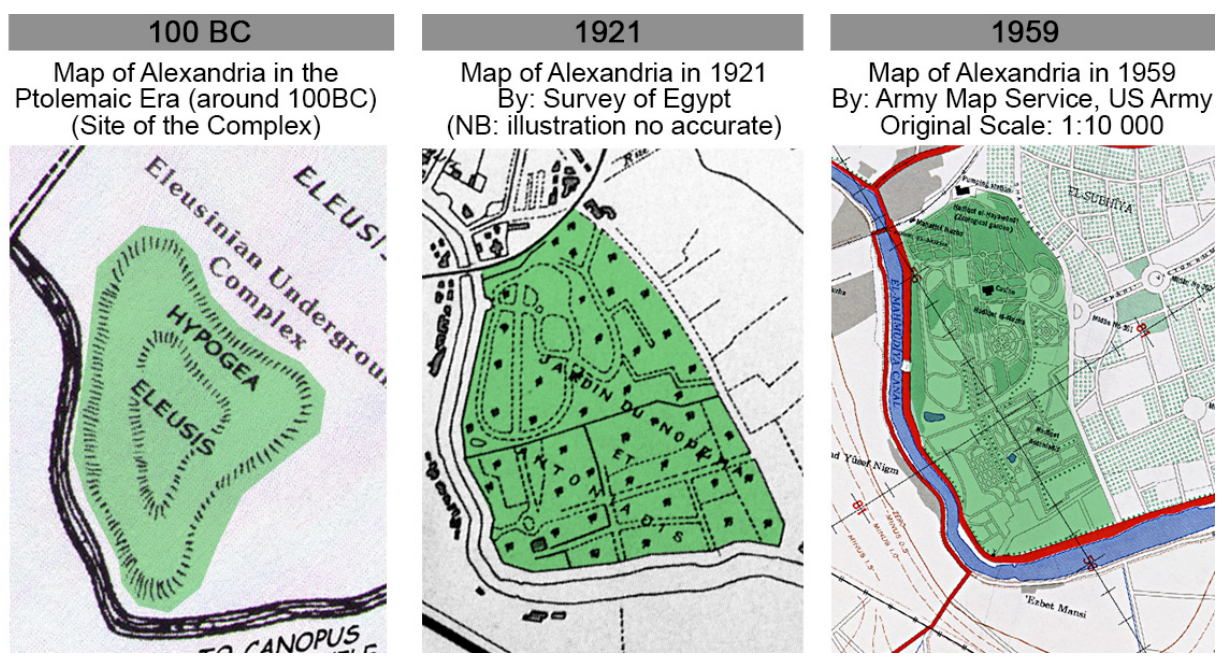

Figure 2: Historical development of Nouzha Complex (assembled by author).

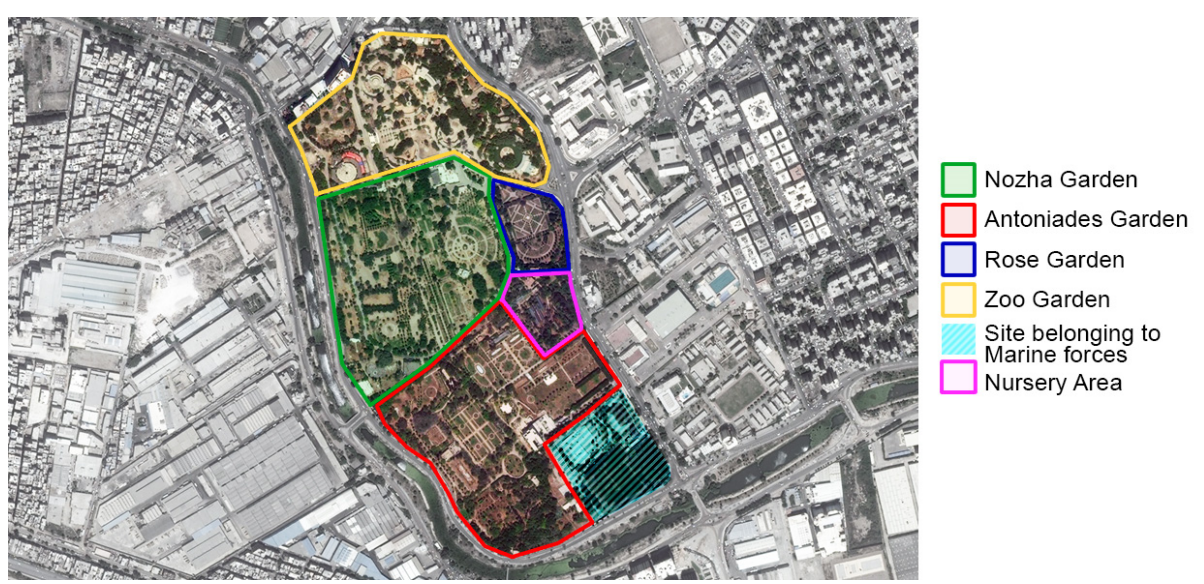

Figure 3: Nouzha Complex garden subdivisions (assembled by author).

\subsubsection{Antoniadis Gardens}

Antoniadis Gardens compose a large portion of the Nouzha Complex. The gardens and palace were established in 1860 by Sir John Antoniadis, and were opened to the public following 1952 Revolution [8]. A Greek architect, Paul Lascaris, designed Antoniadis Palace and Gardens, and two Belgian landscapers, Monfront Bey and Paul Richard (Director of Alexandria's gardens) embellished the garden on the model of the seventeenth-century Versailles gardens with avenues of trees and a terrace raised above the parterres [7]. These gardens bore witness to various important historical events, and hosted numerous historical figures. It hosted the signing ceremony of the 1936 agreement between Cairo and Britain as well as the first meeting of the Egyptian Olympia committee. Among the historical figures that spent time at the gardens was Shah of Iran Reda Bahlawi, spending his honeymoon with his Egyptian wife princess there [8]. 
The Gardens house a collection of statues (Fig. 4) sculpted in the Greek style and originally owned by Sir John Antoniadis. The Palace footprint is beyond 1000 square meters. There are also archaeological remains, including a Gnostic tomb and a cistern. The Palace is listed as a historical monument number 1250 in the Governorate conservation registry [9]. Antoniadis Gardens design is characterized by different styles that include:

1. Arab-Andalusian features, characterized by a high wall of Cupressus trees to conceal the internal views and waterfalls and fountains;

2. French geometric features, characterized by straight lines and the symmetry of the roads, fences, ornamental basins and clipped trees (conical, pyramidal, square and rectangular) (Fig. 5);

3. Graeco-Roman features, characterized by fountains (there are seven throughout the Antoniadis garden);

4. Italian features, characterized by terracing and statues; and

5. natural features, characterized by a lack of decoration or complexity and the plants cultivated in diverging or converging pattern [7], [10].

Recently, Alex-Med (Alexandria and Mediterranean Research Centre) has developed a renovation project to preserve and manage Antoniadis Palace and Gardens as a source of enrichment and pleasure to future generations. Palace will host some Bibliotheca Alexandrina events, but will also become a centre for scholarship on Alexandria and Mediterranean and a space for exchange and dialogue. It is expected to therefore become a Med Research Centre and a guesthouse for visitors and researchers, as it should contain a museum with exhibition space, along with thematic gardens, a horticulture centre and an outdoor theatre [11]. The layout in Fig. 6 shows the current design and divisions within Antoniadis Gardens, which comprise the different smaller gardens as well as the main palace.
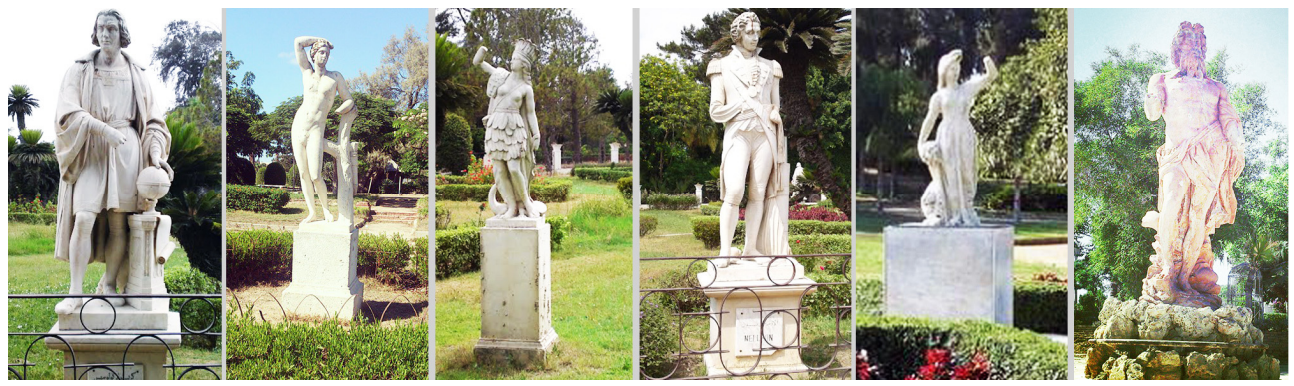

Figure 4: Collection of statues in Antoniadis gardens.
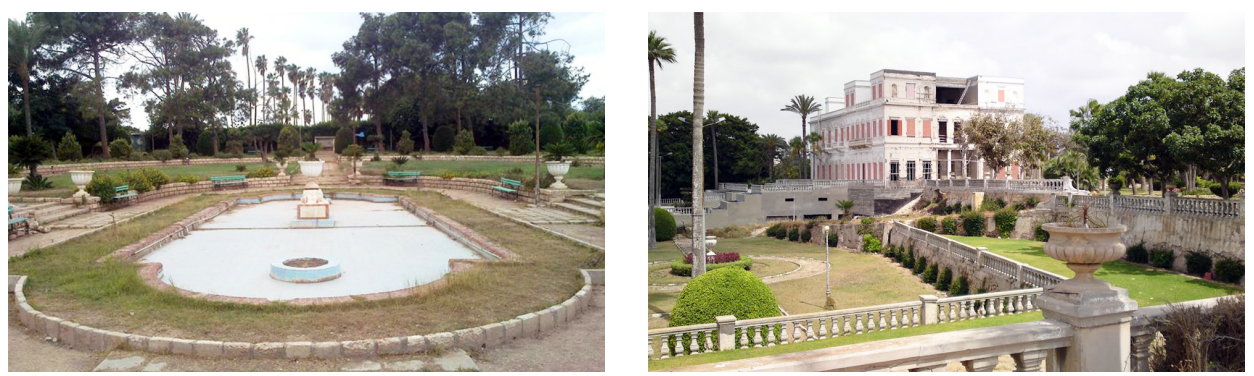

Figure 5: Left: Antoniadis Palace and front garden (2013). Right: French Garden (2013). 


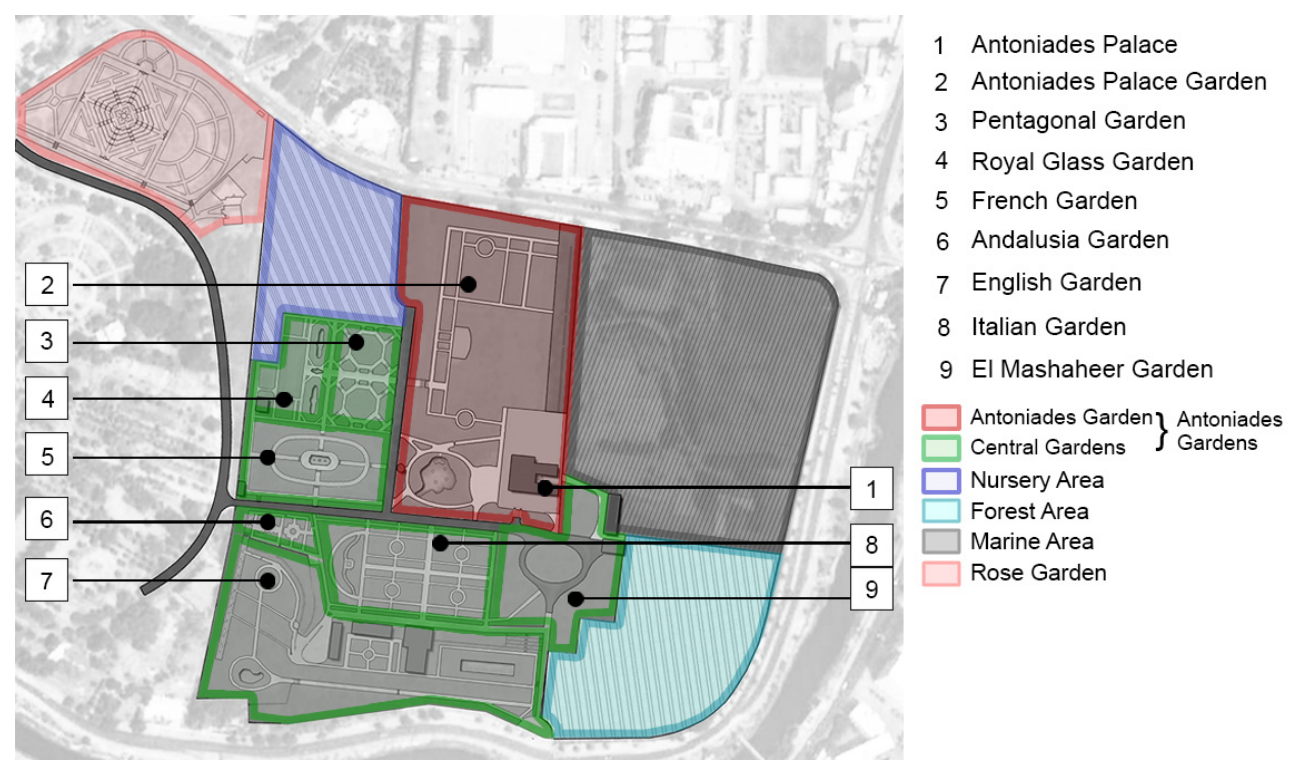

Figure 6: Antoniadis Gardens divisions and functions [12]. (Source: Arafa, 2013. Developed by author.)

The current status of the gardens and the palace is highly deteriorated, since there is a lack of maintenance and direct funding to upkeep and restore the existing design elements and components. The hardscape and landscape furniture is of medium condition (proportional to material durability), yet the softscape and ground covers are facing higher risk of wear. It is worth mentioning that the community awareness of the significance of this site is alarming, since it is not a major attraction point to the public anymore, and hence many contemporary functions have intruded on the site, such as a local nursery and a marine base.

\subsubsection{Rose Garden}

The Rose Garden was laid out by the French master-gardener Barillet-Deschamps. It is featured as a "sunken garden" (Fig. 7), with descending levelling towards the middle. The middle and lowest part of the garden contains a fountain with a central classic stature. The garden is designed on 4-levelled terraces and enclosed within 4 wooden pergolas [7].

\subsubsection{Alexandria Zoo Garden}

The area where the zoo stands today was originally the part of the Nouzha Garden in the complex. In 1907, part of the Nozha Garden was taken and the Zoo Garden was established in its place (remaining original features are highlighted in Fig. 8) [7]. The zoo comprises various species of tigers, lions, birds and other African animal species. Inside the zoo lies a watch tower, from which visitors can overview the zoo features and landmarks using a telescope. The Alexandria zoo is one of the spaces that are popular amongst modest social classes of the community for entertainment and public enjoyment. It is one of the few spaces that are actually utilized for their original purpose and with high community awareness of its activities and accessibility. 

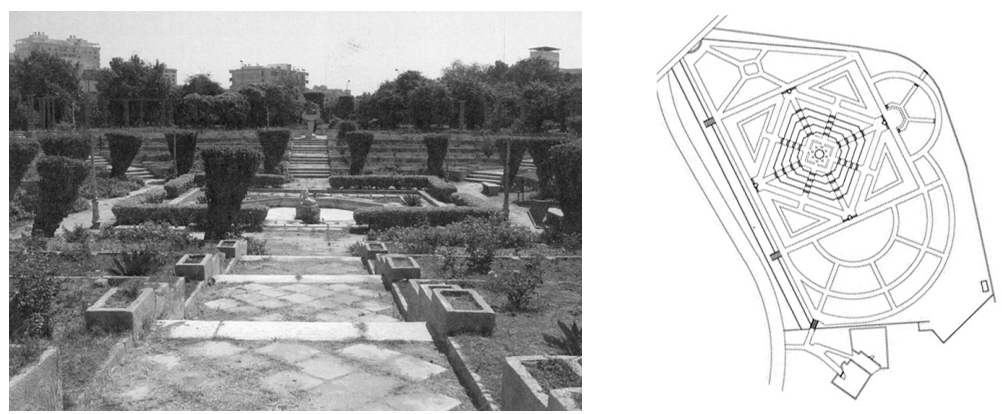

Figure 7: Left: Sunken terraces in Rose Garden (2010). Right: Layout of Rose Garden [12] (developed by author).
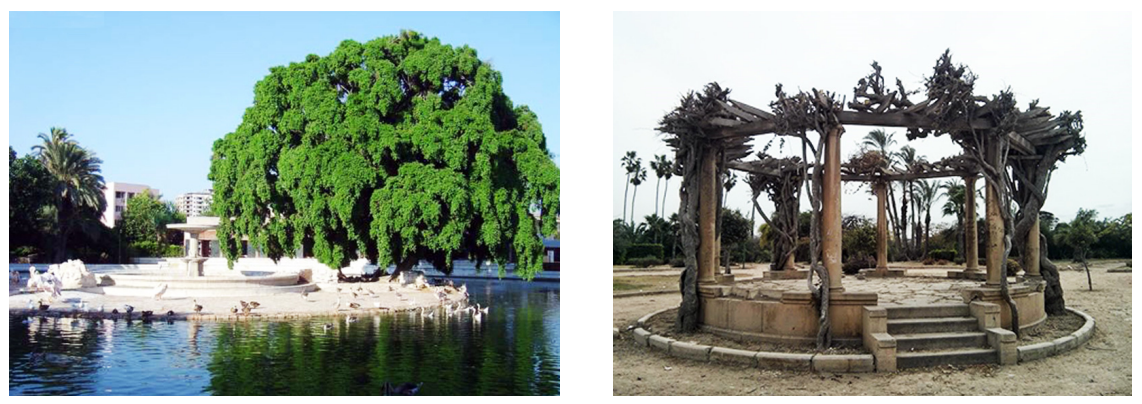

Figure 8: Left: Fountain and Lake. Original zoo design structures (2014). Right: Historical Kiosk. One of the original zoo design elements (2014).

\subsection{Montazah Gardens}

Before the creation of the gardens, the site where the Montazah is today used to be a marvellous area known for its magnificent trees and rare plants, on 2 high hills and a small island to the north. During his reign, Khedive Abbas Hemly Pasha II discovered the site and immediately decided to create a palace there to spend his summer vacations. On one of the two hills there were old canons dating back to the reign of Mohamed Ali Pasha (used for shore protection back then).

These canons still stand in this position, and in front of them, the Salamlek Palace was built as ordered by Abbas Hemly II (Fig. 9). The other hill contained a small building for the coast guard. The Khedive bought the building and replaced it with the Haramlek Palace. The Haramlek Palace design is a magnificent combination between classic, Italian and Islamic architectural styles. The bay was designed as a port for the famous royal yacht, "AlMahroosa" [13]. Al Montazah Palace and gardens were the most favoured summer vacation spot for the royal family till the end of royalty in Egypt. After 1952 revolution, the gardens were opened to the public, and the Salamlek Palace was transformed into a fancy hotel. The Montazah Complex also contains Palestine Hotel, which was built in 1964 overlooking the bay, to host the 2nd Arab Summit held in Alexandria in September 1964. The Montazah Complex was also the home of many movie shootings in the 1950s and 60s [13]. It is also worth mentioning that Montazah has lost $70 \mathrm{~F}$ of its area to urban growth in Alexandria. The original and lost areas are illustrated in Fig. 10. 

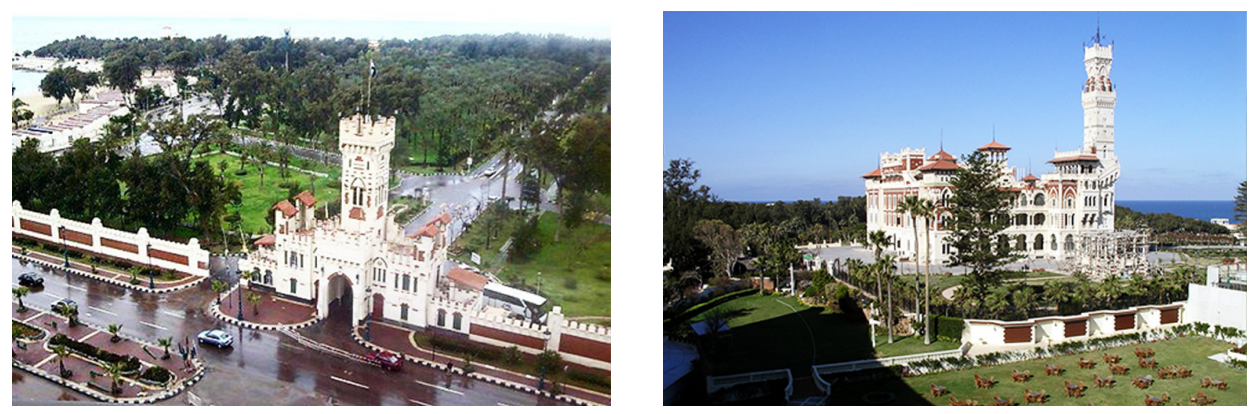

Figure 9: Left: The main entrance gate on the west edge of the gardens. Right: Montazah Palace with merge of classic Italian and Islamic styles.
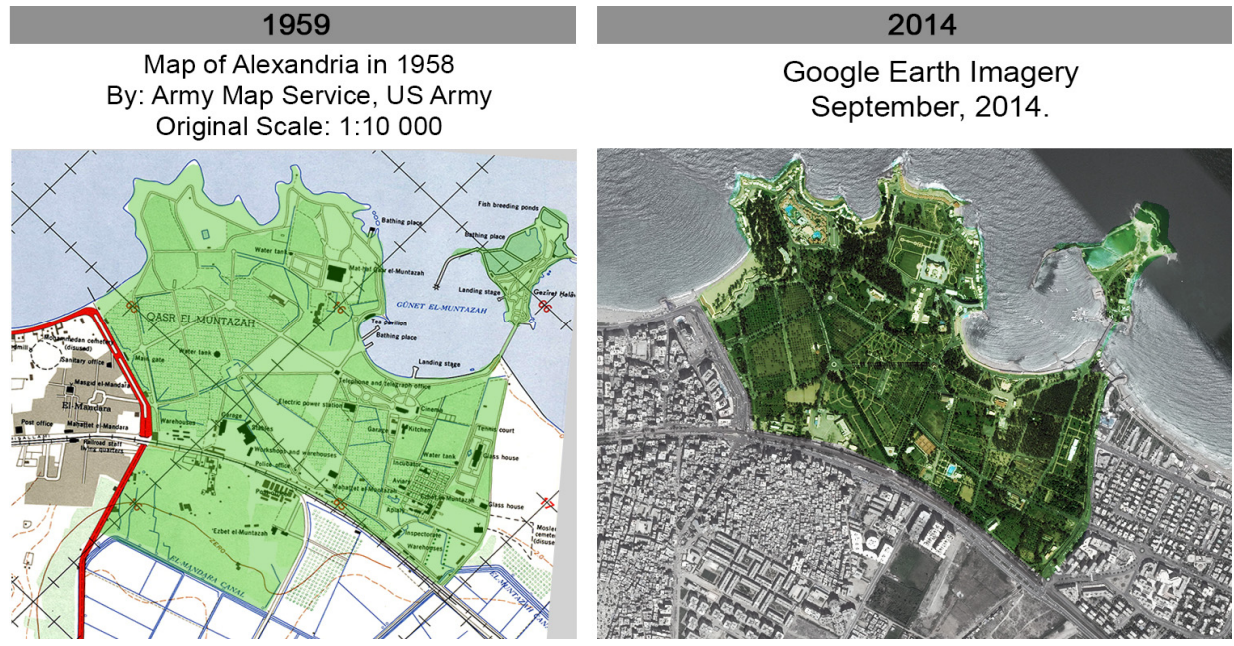

Figure 10: Historical development of Montazah Gardens.

\subsection{Shalalat Gardens}

The Shallalat Gardens are on the site of the royal palace gardens and old Alexandria library of the Graeco-Roman era, and they are now the third largest public park in Alexandria. They were laid out following the ideas of the American landscaper and park-maker Frederick Law Olmsted, and include towers that were once a part of the Ancient Roman Alexandria wall and Copper Fortress, 'Tabia el-Nahassen', where copper tools were manufactured in the era of Mohammed Ali [7]. In 1958, the total area of the gardens was 68 Feddans, but by 1984, after the establishment on the site of the Olympic Club (9.5 Feddans) and the Waterfalls Youth Centre (2.7 Feddans), road expansion, and the construction of a natural gas pipe storage area, its extant was reduced to 41.5 Feddans. In 1999, the expansion of the Suez Canal Road and the construction of the Abdel-Moneim Riad Tunnel, a children's library, the house for the Supreme Council of Antiquities and a police station, it was further decreased to 34 Feddans. Today, the total area of the Northern and Southern parts are less than 30 Feddans. The development of Shallalat historical relics along time is mapped in Fig. 11. The northern 

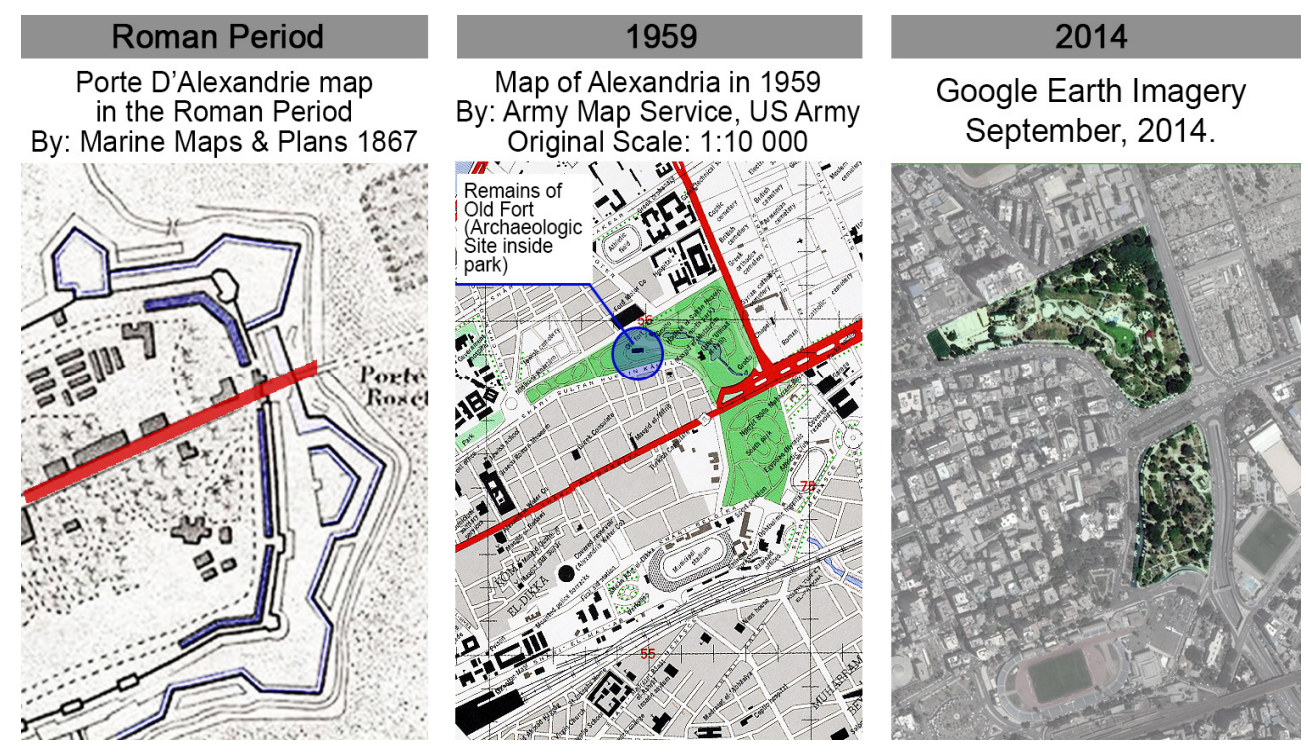

Figure 11: Historical Development of Shalalat Gardens (assembled by author).

garden is characterized by its natural style consisting of elevations and depressions, an artificial pond and a large waterfall where Adiantum capillus-veneris is grown [7].

The Shallalat Gardens are the only site in the two studied cities with an archaeological area (remains of the old Alexandria fort) in the middle of the park, which is quite unique in terms of historical parks and gardens in Egypt.

\section{DISCUSSION}

Analysing the urban ratio of the historical parks and gardens in Alexandria as shown in the map in Fig. 1, it is quite apparent that the ratio of and percentile of historical parks in the city is quite low. However, when reviewing the changes in areas along time for each park, only Montazah garden lost a significant $19 \%$ of its area to urban growth as shown in Table 1 (while the current status of the remaining part is highly maintained). This is an indication of the municipal as well as the community awareness of the importance of these parks and their influence on the urban identity of the city, unlike other metropolises in Egypt such as Cairo, where the parks and gardens are losing more than $70 \%$ of their area (Azbakeya garden) [14]. Nearly all the reviewed parks were established in the 19th and early 20th centuries, and usually designed by French or English master-gardeners, which corresponds to the Royal Era of Mohammed Ali Pacha's family in Egypt, and the westernization cultural influence that accompanied this period.

The current status and deterioration in the physical components of the parks can be viewed clearly in Nouzha Complex, especially Antoniadis gardens and palace. Other parks such as Montazah and Shalalat are well-maintained, which reflects on the municipal and funding availability for the parks. In the case of Antoniadis gardens, the land plot is deserted and accounted for as unused land, whereas the presence of hotels, entertainment facilities and investors in Montazah has led to its nourishment and preservation. 
Table 1: Collective overview of park information according to their profiles.

\begin{tabular}{|c|c|c|c|c|c|c|}
\hline Park/garden & Year founded & Ordered by & $\begin{array}{l}\text { Gardener / } \\
\text { designer }\end{array}$ & $\begin{array}{l}\text { Original } \\
\text { area } \\
\text { (Feddans) }\end{array}$ & $\begin{array}{l}\text { Current } \\
\text { area } \\
\text { (Feddans)* }\end{array}$ & $\begin{array}{l}\% \text { Lost } \\
\text { area } \\
\text { (Feddans) }\end{array}$ \\
\hline $\begin{array}{l}\text { Nouzha } \\
\text { Complex } \\
\text { Gardens }\end{array}$ & $300 \mathrm{BC}$ & $\begin{array}{l}\text { Mohamed } \\
\text { Ali Pasha }\end{array}$ & $\begin{array}{l}\text { Various } \\
\text { (including } \\
\text { Deschamps) }\end{array}$ & 110 & 110 & $0 \%$ \\
\hline $\begin{array}{l}\text { Antoniadis } \\
\text { Garden }\end{array}$ & 1860 & -- & $\begin{array}{l}\text { Paul Lascaris, } \\
\text { Monfront Bey } \\
\text { and Paul Richard }\end{array}$ & 45 & 36 & $20 \%$ \\
\hline Nouzha Garden & $300 \mathrm{BC}$ & -- & --- & 79 & 34 & $57 \%$ \\
\hline Rose Garden & 1928 & -- & $\begin{array}{l}\text { Barillet- } \\
\text { Deschamps. }\end{array}$ & 5 & 5 & $0 \%$ \\
\hline $\begin{array}{l}\text { AlexandriaZoo } \\
\text { Gardens }\end{array}$ & 1907 & -- & --- & 2 & 27 & $-1250 \%$ \\
\hline $\begin{array}{l}\text { Montazah } \\
\text { Gardens }\end{array}$ & 1890 & $\begin{array}{l}\text { Khedive } \\
\text { Abbas } \\
\text { Helmy II }\end{array}$ & --- & 370 & 300 & $19 \%$ \\
\hline $\begin{array}{l}\text { Shalalat } \\
\text { Gardens }\end{array}$ & Roman period & $\begin{array}{l}\text { Mohamed } \\
\text { Ali Pasha }\end{array}$ & $\begin{array}{l}\text { Frederick Law } \\
\text { Olmsted }\end{array}$ & 67.5 & 30 & $56 \%$ \\
\hline
\end{tabular}

\section{CONCLUSION}

From the presented framework and historical overview, it can be concluded that the historical parks and gardens in Alexandria present an essential part of its cultural heritage, whereas layers of the city's history is contained within these open spaces. These layers are facing current challenges of urban encroachment from more pressing or profitable land uses. As well as this, the physical deterioration of the parks and gardens is directly related to the availability of funds and attention from both municipalities and investors. The status of these parks and gardens that are threatened by deterioration or encroachment is dependant on different factors, including raising community interaction with the parks as well as their awareness of the significance of the spaces. The decay of the historical payers in these parks can also be evaded through effective management and municipal responsiveness.

\section{REFERENCES}

[1] Secretary General \& Alexandria Governorate, "Alexandria City Development Strategy (CDS) \& Alexandria Growth Pole Project," 2006.

[2] Abdou Aziz, L.K., "Urban growth in Alexandria, Egypt using remote sensing and GIS Doctor of Philosophy at the University," Newcastle University, 2004.

[3] Bell, H.I., Alexandria. J Egypt Archaeol, 13(3/4), pp. 171-184, 1927.

[4] UN-HABITAT (United Nations Centre for Human Settlements), State of the world's cities 2012/2013 - prosperity of cities, 2013.

[5] Saad El Din, M., Steen, G.L. \& De Luca, A., Alexandria: The Site and the History, New York University Press: New York, 1993.

[6] Ilbert, R., Alexandrie 1830-1930, Histoire D'une Communité Citadaine, 1996.

[7] Hamdy, R., A study of plant distribution in nine historic gardens in Egypt. Gard Hist, 28(2), pp. 267-314, 2010.

[8] Alexandria Governorate, "Alexandria City; Antoniadis Gardens."

[9] Bibliotheca Alexandrina, "Antoniades Gardens," http://www.bibalex.org/food/ venue.html 
[10] Khalifa, S.F., The Botanical Gardens, Past, Present and Future, Cairo, 1995.

[11] Awed, Z., "Antoniadis Villa and Its Gardens."

[12] Arafa, A., "Antoniadis Botanic Garden, a foothold for native plants emphasis in Egypt," in Planting Design 2013 Working Group 2 - Case Study, 2013.

[13] State Information Service (SIS), "Gardens of Alexandria," 2014.

[14] Abd El Aziz, N., "Designing and Managing Urban Parks to Improve the Quality of Life in the Egyptian Cities," Thesis, Cairo University, Cairo, 2012. 